\title{
Sarcospan: a small protein with large potential for Duchenne muscular dystrophy
}

\author{
Jamie L Marshall ${ }^{1,2}$ and Rachelle H Crosbie-Watson ${ }^{1,2,3^{*}}$
}

\begin{abstract}
Purification of the proteins associated with dystrophin, the gene product responsible for Duchenne muscular dystrophy, led to the discovery of the dystrophin-glycoprotein complex. Sarcospan, a 25-kDa transmembrane protein, was the last component to be identified and its function in skeletal muscle has been elusive. This review will focus on progress over the last decade revealing that sarcospan is an important regulator of muscle cell adhesion, strength, and regeneration. Investigations using several transgenic mouse models demonstrate that overexpression of sarcospan in the mouse model for Duchenne muscular dystrophy ameliorates pathology and restores muscle cell binding to laminin. Sarcospan improves cell surface expression of the dystrophin- and utrophin-glycoprotein complexes as well as a $\beta \beta 1$ integrin, which are the three major laminin-binding complexes in muscle. Utrophin and a7 $\beta 1$ integrin compensate for the loss of dystrophin and the finding that sarcospan increases their abundance at the extra-synaptic sarcolemma supports the use of sarcospan as a therapeutic target. Newly discovered phenotypes in sarcospan-deficient mice, including a reduction in specific force output and increased drop in force in the diaphragm muscle, result from decreased utrophin and dystrophin expression and further reveal sarcospan's role in determining abundance of these complexes. Dystrophin protein levels and the specific force output of the diaphragm muscle are further reduced upon genetic removal of a7 integrin (Itga7) in SSPN-deficient mice, demonstrating that interactions between integrin and sarcospan are critical for maintenance of the dystrophin-glycoprotein complex and force production of the diaphragm muscle. Sarcospan is a major regulator of Akt signaling pathways and sarcospan-deficiency significantly impairs muscle regeneration, a process that is dependent on Akt activation. Intriguingly, sarcospan regulates glycosylation of a specific subpopulation of adystroglycan, the laminin-binding receptor associated with dystrophin and utrophin, localized to the neuromuscular junction. Understanding the basic mechanisms responsible for assembly and trafficking of the dystrophin- and utrophin-glycoprotein complexes to the cell surface is lacking and recent studies suggest that sarcospan plays a role in these essential processes.
\end{abstract}

Keywords: Akt, Cell adhesion, Duchenne, Dystrophin, Integrin, Laminin-binding, mdx, Muscular dystrophy, Neuromuscular junction, Regeneration, Sarcolemma, Sarcospan, Utrophin

\section{Review}

\section{Identification of sarcospan}

Muscular dystrophies represent a group of progressive muscle disorders characterized by extensive muscle wasting and weakness. Duchenne muscular dystrophy (DMD) is caused by mutations in the dystrophin gene

\footnotetext{
* Correspondence: rcrosbie@physci.ucla.edu

'Department of Integrative Biology and Physiology, University of California Los Angeles, 610 Charles E. Young Drive East, Terasaki Life Sciences Building, Los Angeles, CA 90095, USA

${ }^{2}$ Center for Duchenne Muscular Dystrophy, University of California Los Angeles, Los Angeles, CA 90095, USA

Full list of author information is available at the end of the article
}

that result in loss of dystrophin, a protein that is normally localized to the subsarcolemma [1-5]. Discovery of dystrophin-associated proteins, referred to as the dystrophin-glycoprotein complex (DGC), represent a major advancement in the understanding of the DGC's function in skeletal muscle and provide further support for the contraction-induced sarcolemma injury model underlying DMD pathogenesis $[1,2,4,5]$. In addition to dystrophin, the DGC is composed of $\alpha / \beta$-dystroglycan (DG), the sarcoglycans (SGs), the syntrophins, and dystrobrevin (for review, [6]). One of the last components of the DGC to be identified was a $25-\mathrm{kDa}$ dystrophin-

\section{() Biomed Central}


associated protein (DAP), which was resistant to identification, in part due to lack of polyclonal antibodies that cross-reacted with the $25-\mathrm{kDa}$ DAP (also called A5) from goats and sheep, immunized with the DGC [7]. The hydrophobic probe, 3-trifluoromethyl-3- $\left(m-\left[{ }^{125} \mathrm{I}\right]\right.$ iodophenyl) diazirine or TID, bound very strongly to the $25-\mathrm{kDa}$ DAP, suggesting that it might be an integral membrane protein [5]. In fact, TID binding to the $25-\mathrm{kDa}$ DAP was greater than its binding to the SGs or $\beta$-DG, which possess a single transmembrane span, providing strong evidence that the $25-\mathrm{kDa}$ DAP contained multiple membrane-spanning regions and was unlikely to be a protein degradation product, as had been speculated based on its weak staining with CoomassieBrilliant blue [5,7]. Identification of the $25-\mathrm{kDa}$ DAP was accomplished by in-gel digestion and sequencing of two amino acid peptides, leading to isolation of the corresponding human cDNA [7] that was previously identified in part as Kirsten ras associated gene (krag), a gene that is co-amplified with Ki-ras in the Y1 murine adrenal carcinoma cell line $[8,9]$. The gene was renamed to sarcospan (SSPN) for its multiple sarcolemma spanning helices predicted from hydropathy analysis [7]. While SSPN is expressed in many non-muscle tissues $[10,11]$, its biochemical characterization was performed in skeletal muscle where it is most abundant.

\section{Rigorous criteria define components of the dystrophin- glycoprotein complex}

Although characterization of the 25-kDa DAP led to its identification, there was much speculation that SSPN was a contaminant of the purified complex rather than a bona fide member of the DGC. Integral components of the DGC are defined by four biochemical characteristics and SSPN was rigorously tested with these established criteria. First, purification of the DGC from skeletal muscle membranes enriches proteins that are associated in a complex with dystrophin. Campbell and colleagues exploited the presence of several glycoproteins within the DGC to enrich the complex using succinylated wheat germ agglutinin (sWGA) lectin chromatography of digitonin-solubilized skeletal muscle membranes [1-5]. sWGA enrichments containing the DGC can be further purified by diethylaminoethyl (DEAE)-cellulose ion exchange chromatography, which separates the DGC from abundant calcium channels. It was discovered that SSPN elutes from DEAE columns at $175 \mathrm{mM} \mathrm{NaCl}$, along with purified DGC components [7]. A second characteristic of DGC proteins is their migration as a complex during high-speed centrifugation through sucrose gradients. Only proteins that bind with high affinity and specificity will be retained with dystrophin during sucrose gradient fractionation where it migrates as an $18 \mathrm{~S}$ complex $[2-4,12]$. SSPN co-migrates with peak
DGC-containing fractions providing additional evidence that SSPN is an integral component of the DGC $[5,7,13,14]$. In contrast, while a fraction of caveolin-3 maintains association with the DGC during purification by sWGA lectin affinity chromatography, it is localized to heavier fractions during sucrose gradient centrifugation $[7,13]$. For the third criterion, the laminin binding capacity of $\alpha$-dystroglycan ( $\alpha-D G$ ) was exploited to separate the DGC from other membrane-associated proteins. Application of sWGA enrichments from skeletal muscle reveals that SSPN is entirely retained on laminin-sepharose columns, but caveolin-3 is found only in the void fraction [13,15-19]. Finally, it is well established that core components of the DGC depend on dystrophin for localization to the sarcolemma. In dystrophin-deficient DMD patients and the $m d x$ mouse model, SSPN is absent from the sarcolemma while membrane expression of caveolin-3 is not affected by loss of dystrophin $[7,13]$.

\section{Structural analysis of sarcospan provides insight into function}

Topology algorithms predict that SSPN possesses four transmembrane domains with a small extracellular loop (between transmembrane domains 1 and 2), a large extracellular loop (LEL; between transmembrane domains 3 and 4), and intracellular N- and C-termini (Figure 1) [7]. Although several protein families contain four transmembrane domains, dendrogram analysis suggests that SSPN is related to the tetraspanins, although not all characteristics are conserved. Like other tetraspanins, the LEL of SSPN contains conserved Cys residues that are important for tertiary structure, although SSPN lacks the hallmark Cys Cys Gly motifs within the LEL and conserved sites for $\mathrm{N}$-linked glycosylation and palmitolyation that are characteristic of tetraspanins [20]. Tetraspanins facilitate protein interactions by forming tetraspanin-enriched microdomains within the membrane to regulate intracellular cell signaling (for review, [20-23]). Similarly, SSPN forms higher ordered homo-oligomers by laterally associating with one another in the sarcolemma of skeletal muscle (Figure 1) [24].

Reconstitution of SSPN oligomerization using a heterologous cell expression system and muscle lysates from SSPN transgenic mice reveals the presence of pentamers that were maintained during high-speed ultracentrifugation through non-reducing sucrose gradients (Figure 1) [24]. Using a site-directed mutagenesis approach, SSPNSSPN interfaces were defined within the intracellular (N- and C-termini) and extracellular regions of SSPN, suggesting that the formation of SSPN oligomers occurs through a complex set of protein interactions (Figure 1). Alanine replacement of cysteine residues reveals that intramolecular thiol bridges between Cys 162 and Cys 


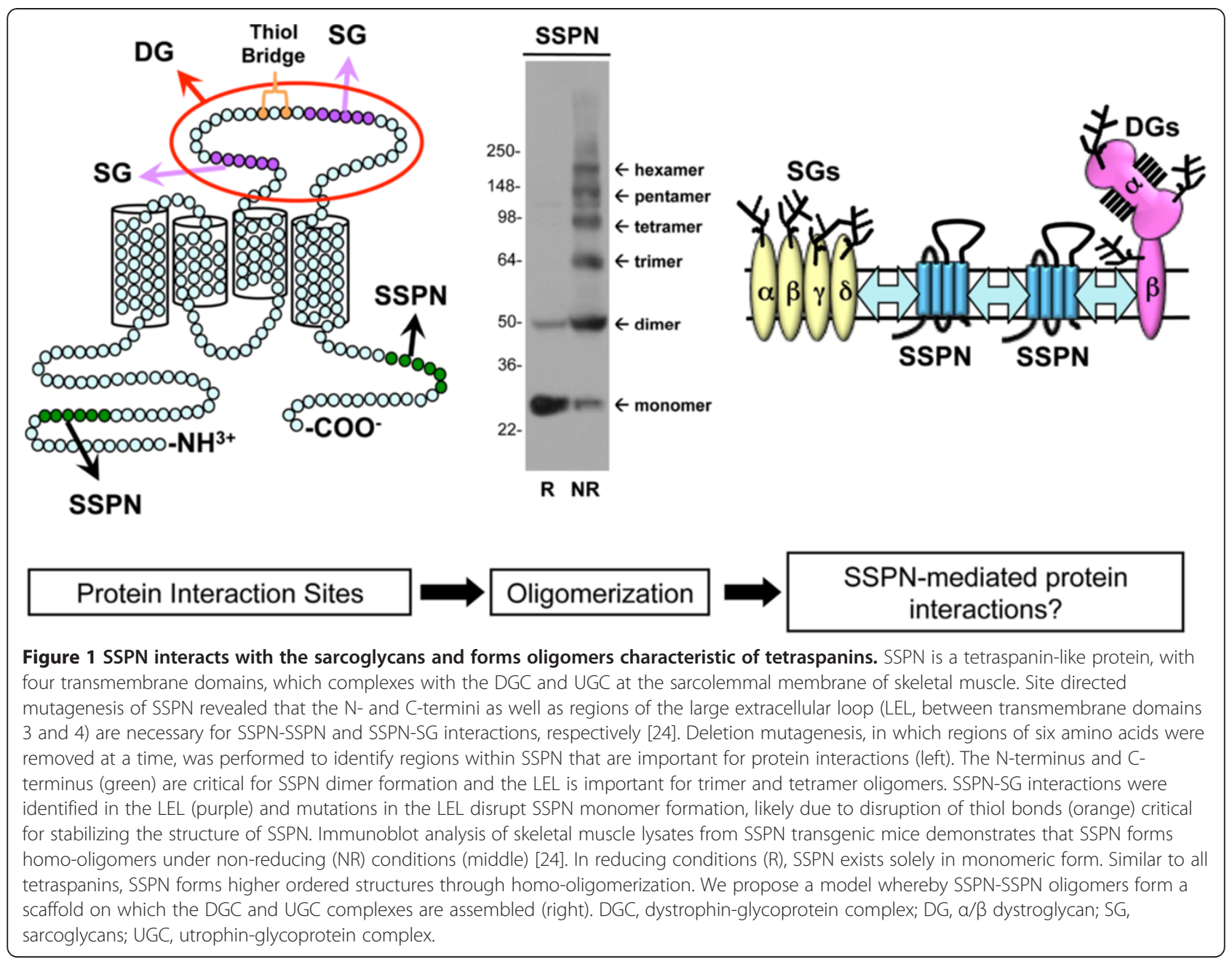

164 within the LEL are critical determinants of SSPN structure [24]. In fact, mutation of any cysteine within the LEL disrupts cysteine packing within the LEL, leading to destabilization of SSPN monomer formation [24]. Based on structural and functional analysis of SSPN overexpression in several mouse models, it is reasonable that multiple SSPN proteins may interact with each adhesion complex, thereby mediating cross-talk between transmembrane glycoprotein complexes. The biological significance of SSPN oligomers mediating proteinprotein interactions between adhesion complexes is appealing, but requires further investigation.

Although SSPN exhibits many tetraspanin-like characteristics, it may be more structurally similar to the CD20 family of proteins, which includes the beta subunit of the high affinity receptor for IgE Fc [25]. Members of the CD20 family span the plasma membrane four times and possess a LEL (between transmembrane domains 3 and 4) as well as intracellular N- and C-termini [26-29]. The regions of homology that define the CD20 family are largely within the transmembrane domains. Similar to tetraspanins, CD20 forms multimeric oligomers within the plasma membrane and is unlikely to exist solely in a monomeric state [30]. The specific function of CD20 has not been elucidated, but CD20 localizes to lipid rafts where it may play a role in regulating cell cycle progression, tyrosine kinase-dependent signaling, and B-cell differentiation (for review, [31]).

\section{Sarcospan and the sarcoglycans form a subcomplex}

The SGs are single pass transmembrane glycoproteins referred to as $\alpha-, \beta-, \gamma-$, and $\delta$-SG (for review, [6]). The first evidence that the DGC is composed of biochemically distinct subcomplexes came from experiments in which purified DGC was subjected to alkaline conditions that dissociate $\mathrm{pH}$-sensitive protein interactions [4]. The finding that SSPN tightly associates with the SG subcomplex is supported by sucrose gradient analysis of alkaline-treated preparations revealing that SSPN co-sediments exclusively with the SGs [32]. Furthermore, treatments with denaturing agents such as sodium dodecyl sulfate [33] and n-octyl $\beta$-D-glucoside [34] fail 
to disrupt the integrity of the SG-SSPN subcomplex. Finally, the SG-SSPN subcomplex can be reconstituted in an in vivo cell culture model system lacking expression of DGs and dystrophin [32]. SSPN also associates with the SGs in smooth muscle purified from kidney and lung tissues [35-38] as well as epididymal white adipose tissue [11].

Mutations in the $\alpha-, \beta-, \gamma^{-}$, or $\delta$-SG genes cause autosomal recessive limb-girdle muscular dystrophy (ARLGMD) type 2D, 2E, 2C, and 2F, respectively (for review, [39]) leading to absence or a significant reduction in the SG subcomplex from the sarcolemma (for review, [40]). Genetic ablation of individual SG genes in mice has generated robust animal models for the SG-deficient ARLGMDs in which the entire SG complex is absent from the sarcolemma (for review, [40]). Similarly, a large deletion in the $\delta$-SG gene causes cardiomyopathic and myopathic features in the BIO14.6 hamster model [41,42]. Consistent with its tight biochemical association with the SGs, SSPN is absent from the sarcolemma of mice deficient in $\alpha$-, $\beta$-, and $\delta$-SG as well as the $\delta$-SG deficient BIO14.6 hamster [32,36,43-46]. SSPN expression is restored to normal levels in BIO14.6 muscle after delivery of an adenovirus encoding $\delta$-SG [32]. Furthermore, investigation of over 30 AR-LGMD muscle biopsies with primary mutations in $\alpha-, \beta-$, or $\gamma-S G$ genes that result in either complete or partial absence of the SGs revealed that SSPN was absent from the sarcolemma [46]. The levels of SSPN expression were not analyzed in $\gamma$-SG deficient mice [47], but it would be interesting to determine if the trend was similar to the observations made in human AR-LGMD biopsies. Interaction between the SGs and SSPN is very sensitive to structural perturbations within the LEL of SSPN, as revealed by alanine scanning and deletion mutagenesis within the LEL (Figure 1) [24]. SSPN interaction with the SGs is not unique to skeletal muscle. The SSPN-SG subcomplex has been characterized in many tissues, including the smooth muscle from lung and kidney [11,35,48-51]. In this context, SSPN interacts with a modified SG subcomplex consisting of $\beta-, \gamma-$, and $\varepsilon$-SG (a homolog of $\alpha$-SG). Interestingly, the SSPN-SG subcomplex does not co-migrate in sucrose gradient fractions of sWGA purified DG from epithelial cells derived from lung or kidney tissue [35]. SSPN is not conserved in Drosophila melanogaster and Caenorhabditis elegans, thus the resulting DGC equivalent lacks SSPN and is predicted to be composed of DGs, SGs, and dystrophin [52,53].

\section{Sarcospan uniquely increases abundance of laminin- binding complexes}

The functional replacement of utrophin for dystrophin is one of many attractive therapeutic strategies for the treatment of Duchenne muscular dystrophy. Utrophin is an autosomal homolog of dystrophin and forms a functionally similar utrophin-glycoprotein complex (UGC) where utrophin replaces dystrophin [54-56]. In normal muscle, the UGC is located at the postsynaptic membrane of neuromuscular junctions (NMJ) [55,57,58]. Overexpression of both full-length utrophin and miniconstructs ameliorates dystrophic pathology in the $m d x$ mouse model of DMD [59-68]. Mice engineered to overexpress threefold levels of human SSPN driven by the muscle-specific human skeletal actin promoter increased ectopic expression of utrophin, dystrophin, and $\alpha 7 \beta 1$ integrin at the sarcolemma (Figure 2) [19,69]. In fact, analysis of SSPN transgenic mice overexpressing 0.5and 1.5-fold levels of SSPN reveals that these molecular events occur in a SSPN dose-dependent manner (Figure 2). Introduction of SSPN (threefold) ameliorates dystrophy in the $m d x$ mouse model of DMD by reducing cycles of degeneration/regeneration and preventing sarcolemma damage (Figure 3). Biochemical purification of the UGC complex using lectin affinity chromatography followed by sucrose gradient ultracentrifugation revealed that SSPN is a component of the UGC $[19,69]$. Consistent with the role of SSPN in regulating adhesion complexes at the cell surface, overexpression of 10-fold levels of SSPN causes formation of insoluble protein aggregates at the sarcolemma, resulting in muscle pathology [70]. To date, thirteen human SSPN transgenic lines have been created and only one line expressed tenfold levels of SSPN. In both 3- and 1.5-fold lines of SSPN expression, internal down regulation of endogenous SSPN was observed, suggesting that the levels of SSPN are tightly controlled within the cell [19]. Based on this data, it may be unlikely to achieve tenfold levels of SSPN in a clinical setting. Future studies are needed to determine whether SSPN amelioration of dystrophic pathology occurs in aged $m d x$ mice and whether SSPN ameliorates disease in mouse models of laminindeficient congenital muscular dystrophy and SGdeficient LGMD.

\section{Sarcospan affects glycosylation of a-dystroglycan}

The cytotoxic T cell (CT) GalNAc transferase (Galgt2) is confined to the NMJ and catalyzes addition of the terminal $\beta 1,4$ GalNAc residues onto the CT carbohydrate of a subset of $\alpha$-DG proteins [71,72]. $\alpha$-DG is the predominant glycoprotein modified with the CT carbohydrate in skeletal muscle where it is enriched at the postsynaptic membrane of the NMJ [73]. Overexpression of Galgt2 in $m d x$ mice increases abundance and extrasynaptic expression of $\alpha$-DG modified with the CT antigen, resulting in improved laminin-binding activity [72,73]. Overexpression of SSPN in $m d x$ mice increases GalNAc modifications in a similar manner to the overexpression of Galgt2, as revealed by the increased cell 


\section{A}

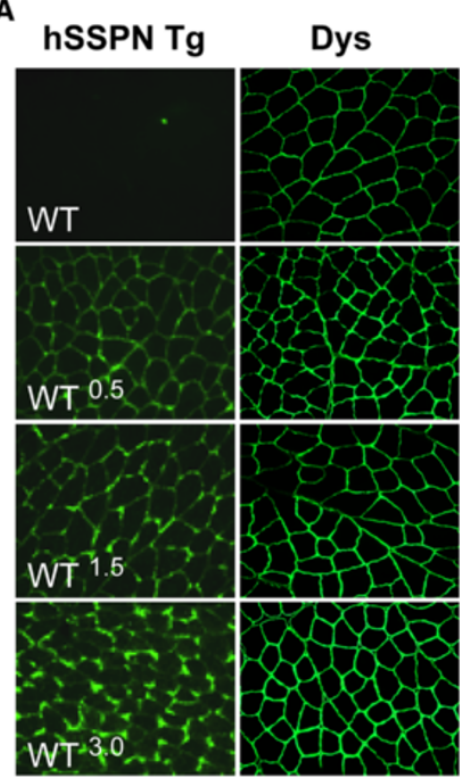

B

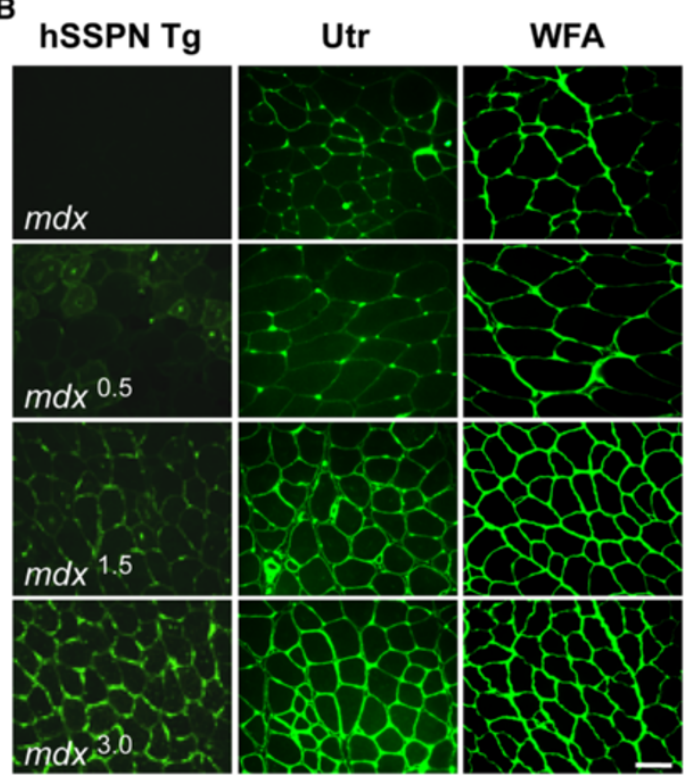

Figure 2 SSPN increases abundance of laminin-binding complexes at the sarcolemma. Several lines of SSPN-transgenic mice with 0.5-, 1.5-, and 3-fold levels of SSPN overexpression were generated to investigate the dose-dependent effects of SSPN expression. SSPN transgenic mice on C57/Bl6 background (WT, WT $T^{0.5}, \mathrm{WT}^{1.5}, \mathrm{WT}^{3.0}$ ) as well as 0.5-, 1.5-, and 3-fold SSPN transgenic on $m d x$ background ( $m d x, m d x^{0.5}, m d x^{1.5}, m d x^{3.0}$ ) were analyzed [19,70]. (A) Transverse cryosections of quadriceps muscle from six-week old SSPN-transgenic mice were stained with antibodies to dystrophin (Dys) and hSSPN to reveal exogenous SSPN expression (hSSPN Tg). (B) Muscle sections from SSPN-transgenic mdx mice were also stained with utrophin (Utr) and hSSPN. Sections overlayed with Wisteria floribunda agglutinin (WFA) lectin reveal increased cell surface glycosylation with elevations in SSPN overexpression [19]. WFA lectin binds terminal GalNAc residues and serves as a marker for the CT antigen modification of a-DG that normally occurs at the NMJ [19]. Note that SSPN increases cell surface expression of dystrophin, utrophin, and glycosylation in a manner dependent on SSPN abundance. Bar, 50 m. CT, cytotoxic T cell; NMJ, neuromuscular junction.

surface binding of the lectin Wisteria floribunda agglutinin (WFA) [19], which is a marker for NMJ-specific CT carbohydrate modification of $\alpha-D G$ (Figure 2) [72,74-77]. WFA binding is localized to NMJs in normal muscle and is increased around the extra-synaptic sarcolemma of $m d x$ muscle cryosections [19,78]. WFA binding to SSPN-transgenic $m d x\left(m d x^{3.0}\right)$ muscle was significantly increased around the extra-synaptic sarcolemma similar to utrophin expression [19]. Increased Galgt2 activity in $m d x$ mice results from a two-fold elevation of Galgt 2 mRNA levels in $m d x$ muscle relative to wild-type controls [73]. However, SSPN does not affect Galgt2 transcript abundance, raising the possibility that SSPN increases Galgt2 activity or improves $\alpha-D G$ as a substrate for Galgt2 [19]. SSPN also increases laminin at the sarcolemma as well as levels of plectin-1, which binds cytoskeletal proteins including $\beta-D G$, dystrophin, utrophin, and F-actin [79-82], supporting the conclusion that SSPN strengthens the structural connection between actin and laminin across the sarcolemma [19]. Furthermore, laminin binding to $\alpha-D G$ was restored to normal levels in threefold SSPN overexpressing $m d x$ muscle [19]. Transgenic overexpression of 0.5 - and 1.5fold levels of SSPN increased glycosylation of $\alpha-D G$, Akt signaling, and utrophin levels, but failed to restore laminin binding or reduce muscle degeneration/regeneration, revealing a minimum (threefold) level of SSPN needed for 'rescue' (Figure 2) [19].

The 'dystroglycanopathies' are a group of disorders resulting from hypoglycosylation of $\alpha-D G$ that abolishes its laminin-binding function. A spontaneous mutation in the $L A R G E$ gene, which encodes an enzyme with xylosyltransferase and glucuronyltransferase activities, causes muscular dystrophy in the myodystrophy ( $m y d)$ mouse [83]. In myd muscle, $\alpha-D G$ is hypoglycosylated and exhibits severely reduced ligand binding activity due to loss of the glycanlaminin binding domain on $\alpha$-DG $[84,85]$. LARGE elongates phosphorylation dependent glycosylaminoglycan modifications on the central mucin domain of $\alpha$-DG by direct interaction with $\alpha-D G[86,87]$. Loss of LARGE increases utrophin and SSPN staining and WFA binding around the extra-synaptic sarcolemma of myd muscle [19]. Introduction of the SSPN transgene into skeletal muscle of $m y d$ mice further elevated WFA binding along with broad, extra-synaptic localization of utrophin, while removal of SSPN from myd muscle reduced utrophin and GalNAc-glycan modification of $\alpha$-DG [19]. Pathology of myd muscle was unaffected by the loss of SSPN or SSPN overexpression, demonstrating that alterations in GalNAc glycosylation of $\alpha-D G$ or utrophin abundance do not affect absence of the main laminin- 

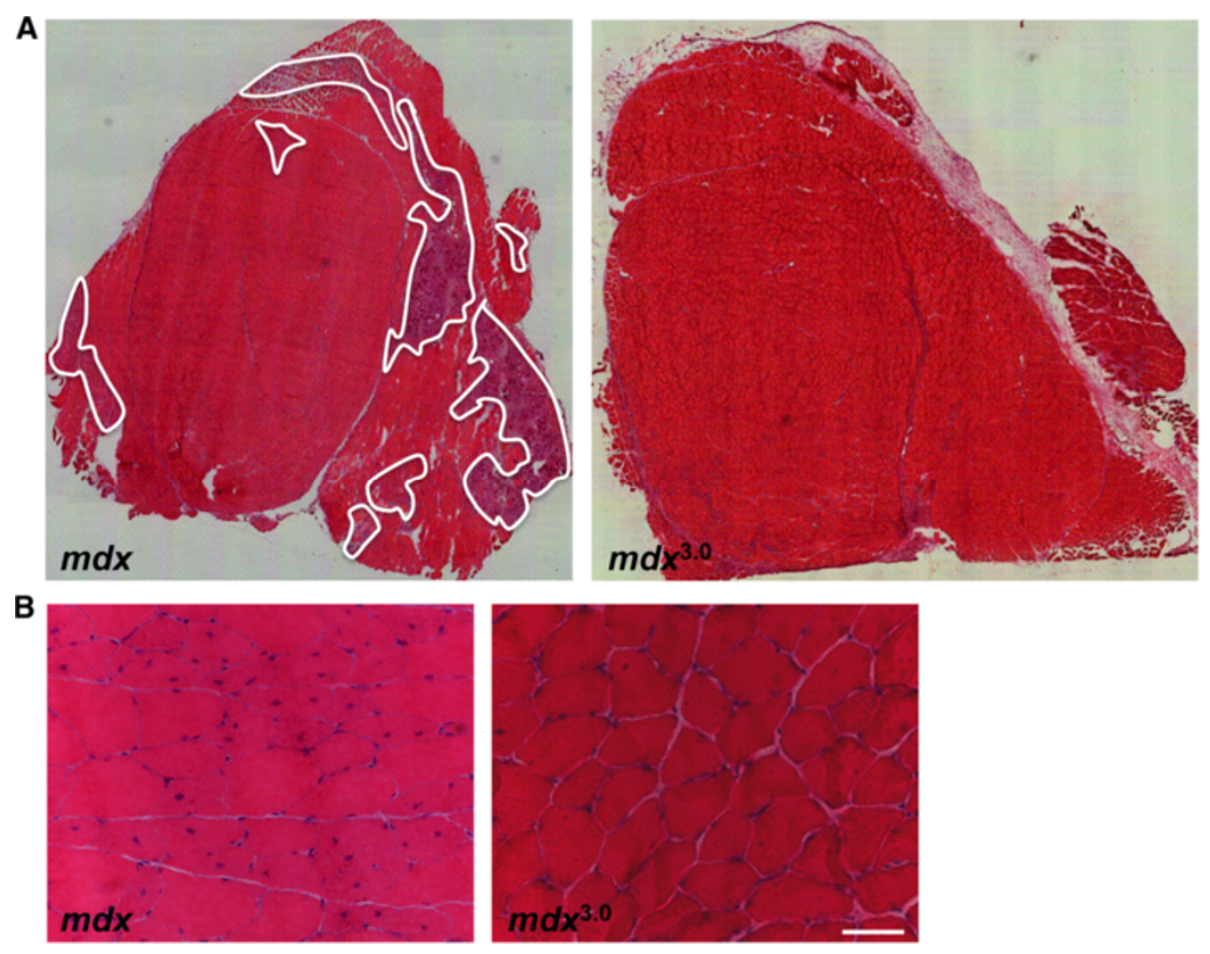

Figure 3 SSPN overexpression ameliorates dystrophic pathology in $\mathbf{m d x}$ mice. Transverse cryosections of quadriceps muscle from six-week old $m d x$ and SSPN transgenic $m d x\left(m d x^{3.0}\right)$ mice were stained with hematoxylin and eosin (H\&E) and visualized at low magnification to reveal the extensive areas of necrosis, denoted in white, in $m d x$ muscle (A). Necrosis was significantly diminished in SSPN transgenic mdx muscle [69]. Sections were also viewed at higher magnification for evaluation of degeneration/regeneration, which is marked by central nucleation of myofibers (B). Overexpression of SSPN in mdx muscle dramatically reduced central nucleation [69]. Bar, 50 um.

binding domain on $\alpha$-DG [19]. The conclusion from these experiments is that Galgt2 (or enzyme with similar function) modifies $\alpha$-DG in the absence of 'LARGE' glycans, demonstrating that GalNAc modification of $\alpha$-DG can occur independently of $\mathrm{O}$-mannose-linked glycans. Additionally, these data reveal that GalNAc carbohydrate structures on $\alpha$-DG are unable to compensate for the loss of LARGE glycans, which constitute the major laminin-binding motif.

\section{A newly discovered phenotype for sarcospan-null mice}

Evidence that SSPN loss may affect skeletal muscle was first suggested from comparative microarray analysis revealing a mild decrease in mRNA levels of dystrophin and $\alpha$-SG in SSPN-null muscle [88]. Furthermore, the authors reported increased expression of two genes, osteopontin and the S100 calcium-binding protein calgranulin $\mathrm{B}$, that have been implicated in immunological function and fibrosis [89-91]. A second gene expression study compared hippocampus and cortex of mice exposed to chronic constant hypoxia $(\mathrm{CCH})$ and chronic intermittent hypoxia $(\mathrm{CIH})$. $\mathrm{CCH}$ occurs in chronic lung diseases or at high altitudes while $\mathrm{CIH}$ develops from disorders such as sleep apnea or sickle cell disease. SSPN was one of two identified genes down-regulated in the hippocampus and cortex after both treatments [92].
SSPN knockdown in a cultured glioma cell line (LN-229) did not affect cell division as determined by bromodeoxyuridine (BrdU) incorporation, but did increase vulnerability of glioma cells to hypoxia [92].

Genetic ablation of SSPN did not appear to alter muscle physiology or strength in young mice [93]. However, when SSPN-null mice were analyzed at older ages (4.5 month old), several deficiencies emerged. Reduction in the levels of the UGC and DGC as well as diminished NMJ-specific glycosylation of $\alpha$-DG and decreased laminin-binding was observed in aged SSPN-nulls [14]. Diaphragms from older SSPN-null mice exhibited diminished specific force generating capacity and were more susceptible to eccentric-contraction induced damage as evidenced by the increased percentage drop in force compared to wild-type controls [14]. These physiological phenotypes were not observed in extensor digitorum longus (EDL) or soleus muscles, suggesting that decreased DGC expression in EDL or soleus muscles is insufficient to manifest in loss of muscle strength or sarcolemma damage [14,93].

\section{Sarcospan genetically interacts with integrins}

It is well established that all tetraspanins interact with integrin partners to regulate cell signaling, adhesion, and 
laminin-binding capacity of integrins (for review, $[94,95]$ ). The primary integrin expressed in adult skeletal muscle is $\alpha 7 \beta 1$ integrin, whichis localized at the NMJ and myotendinous (MTJ) regions within the sarcolemma [96-99]. The relatively mild phenotype of $m d x$ mice has been attributed to increased, compensatory expression of both utrophin and $\alpha 7 \beta 1$ integrin in response to loss of dystrophin that, when ablated, exacerbates $m d x$ pathology [100-102]. Overexpression of Itga7 in $m d x$ :utrophin-null mice and $\beta 1$ integrin in $m d x$ mice ameliorates pathology [103-105]. The recent observation that $\alpha 7 \beta 1$ integrin levels are increased in response to SSPN deficiency is intriguing as it suggests that $\alpha 7 \beta 1$ integrin compensates for SSPN function and moderates the severity of muscle phenotypes in SSPN-nulls [14]. Analysis of SSPN-deficient and Itga7-deficient double knockout (DKO) mice supports this hypothesis. In comparison to controls at 4.5-months of age, DKO mice exhibit increased kyphosis and premature lethality at one month of age, which is significant given that the single-nulls display no overt signs of pathology or lethality (Table 1) [14]. Furthermore, DKO muscle appears severely dystrophic with extensive fibrosis surrounding individual hypertrophic muscle fibers, in a manner identical to histological images of DMD biopsies [14]. Genetic removal of Itga7 from SSPN-nulls further reduced levels of the DGC at the sarcolemma, diminished lamininbinding to $\alpha-D G$, and consequently decreased specific force output in the diaphragm (Table 1) [14]. The conclusion from this work is that SSPN is a necessary component of dystrophin and utrophin function and that SSPN modulation of integrin signaling is required for growth, extracellular matrix attachment, and muscle force development.
The table summarizes phenotypic and biochemical data from 4.5-month old SSPN-null, Itga7-null, and SSPN-null: Itga7-null double knockout (DKO) mice. All comparisons are relative to age-matched wild-type mice. Survival studies were carried out to eight months of age. At this time point, $40 \%$ of the DKO mice had succumbed to death compared to less than $5 \%$ of the controls. The extent of kyphosis was documented in 4.5-month and 6-month old mice. Itga7-null mice exhibited minor kyphosis and the additional loss of SSPN caused severe kyphosis in DKO mice. Myofiber cross-sectional area (CSA) quantified from the quadriceps and diaphragm muscles at 4.5 months of age are represented. DKO muscles exhibited an increase in myopathy and increase in very small $\left(0\right.$ to $\left.500 \mu \mathrm{m}^{2}\right)$ myofibers. Central nucleation is provided as an indicator of overall muscle phenotype. Analysis of sarcolemmal damage (Evans blue dye assay) and fibrosis (Van Geison) of the quadriceps and diaphragm muscles at 4.5 months of age are exacerbated in DKOs [14]. The levels of utrophin, dystrophin, laminin-binding to $\alpha-D G$, and $\beta 1$ integrin were analyzed by densitometry of sWGA eluates from digitonin-solubilized total skeletal muscle lysates. SSPNdeficient mice exhibit a reduction in the UGC, DGC, and laminin-binding to $\alpha$-DG and a corresponding compensatory increase in $\beta 1$ integrin [14]. Loss of Itga7 results in a reduction in the levels of the DGC and laminin-binding to $\alpha$-DG. Importantly, combined loss of Itga7 and SSPN causes further reduction of the DGC, UGC, and lamininbinding to $\alpha$-DG compared to all controls. The relative levels of P-Akt/Akt and P-IGFR/IGFR are provided. Specific force measurements of the diaphragm muscles reveal a loss of specific force in SSPN-null and Itga7-null that is additive in DKO mice. Interestingly, specific force production of the EDL and soleus muscles are unaffected by the

Table 1 Sarcospan- and $\alpha 7$ integrin-double nulls display severe growth and muscle phenotypes

\begin{tabular}{|c|c|c|c|c|c|c|c|c|c|c|}
\hline Genotype & $\begin{array}{l}\text { Survival } \\
\text { Analysis }^{\mathrm{a}}\end{array}$ & Kyphosis $^{\mathrm{a}}$ & $\begin{array}{l}\text { Myofiber } \\
\text { CSA }^{a}\end{array}$ & $\begin{array}{c}\text { Central } \\
\text { Nucleation }^{a}\end{array}$ & Utrophin $^{a}$ & Dystrophin $^{a}$ & Integrin $^{a}$ & $\begin{array}{l}\text { Laminin- } \\
\text { Binding }^{a}\end{array}$ & Signaling $^{a}$ & Specific Force $^{a}$ \\
\hline \multirow[t]{2}{*}{ Wild type } & \multirow[t]{2}{*}{$100 \%$} & \multirow[t]{2}{*}{ No } & \multirow[t]{2}{*}{ Normal } & \multirow[t]{2}{*}{ Normal } & \multirow[t]{2}{*}{$100 \%$} & \multirow[t]{2}{*}{$100 \%$} & \multirow[t]{2}{*}{$100 \%$} & \multirow[t]{2}{*}{$100 \%$} & $\begin{array}{l}\text { P-Akt/Akt: } \\
100 \%\end{array}$ & \multirow[t]{2}{*}{$\begin{array}{l}\text { Normal (EDL, Soleus, } \\
\text { Diaphragm) }\end{array}$} \\
\hline & & & & & & & & & $\begin{array}{l}\text { P-IGFR/IGFR: } \\
100 \%\end{array}$ & \\
\hline \multirow[t]{2}{*}{ SSPN null } & \multirow[t]{2}{*}{$100 \%$} & \multirow[t]{2}{*}{ No } & \multirow[t]{2}{*}{ Normal } & \multirow[t]{2}{*}{ Normal } & \multirow[t]{2}{*}{$31 \%$} & \multirow[t]{2}{*}{$47 \%$} & \multirow[t]{2}{*}{$293 \%$} & \multirow[t]{2}{*}{$69 \%$} & $\begin{array}{l}\text { P-Akt/Akt: } \\
49 \%\end{array}$ & \multirow[t]{2}{*}{$\begin{array}{l}\text { Normal (EDL, Soleus); } \\
\text { Decrease (Diaphragm) }\end{array}$} \\
\hline & & & & & & & & & $\begin{array}{l}\text { P-IGFR/IGFR: } \\
80 \%\end{array}$ & \\
\hline \multirow[t]{2}{*}{ Itga7 null } & \multirow[t]{2}{*}{$95 \%$} & \multirow[t]{2}{*}{ Minor } & \multirow[t]{2}{*}{ Normal } & \multirow[t]{2}{*}{ Normal } & \multirow[t]{2}{*}{$102 \%$} & \multirow[t]{2}{*}{$48 \%$} & \multirow[t]{2}{*}{ Absent } & \multirow[t]{2}{*}{$85 \%$} & $\begin{array}{l}\text { P-Akt/Akt: } \\
95 \%\end{array}$ & \multirow[t]{2}{*}{ Decrease (Diaphragm) } \\
\hline & & & & & & & & & $\begin{array}{l}\text { P-IGFR/IGFR: } \\
99 \%\end{array}$ & \\
\hline \multirow[t]{2}{*}{ DKO } & \multirow[t]{2}{*}{$60 \%$} & \multirow[t]{2}{*}{ Severe } & \multirow[t]{2}{*}{ Decrease } & \multirow[t]{2}{*}{ Increase } & \multirow[t]{2}{*}{$44 \%$} & \multirow[t]{2}{*}{$34 \%$} & \multirow[t]{2}{*}{ Absent } & \multirow[t]{2}{*}{$28 \%$} & $\begin{array}{l}\text { P-Akt/Akt: } \\
40 \%\end{array}$ & $\begin{array}{l}\text { Severe Decrease } \\
\text { (Diaphragm) }\end{array}$ \\
\hline & & & & & & & & & $\begin{array}{l}\text { P-IGFR/IGFR: } \\
35 \%\end{array}$ & \\
\hline
\end{tabular}


loss of SSPN suggesting that, in these muscles, integrin may successfully compensate for DGC or that reduction of the DGC does not affect EDL and soleus muscle physiology.

\section{Sarcospan activates Akt signaling pathways to facilitate regeneration}

Modulation of the phosphatidylinositol-3 kinase (PI3K)/ Akt signaling pathway leading to downstream activation of p70S6K protein synthesis pathways is important for regulation of muscle strength, hypertrophy, and pathophysiology (for review, $[106,107])$. The Akt signaling cascade through p70S6K is activated by several receptors, including: insulin like growth factor 1 (IGF-1) and $\beta 1$ integrin associated integrin-linked kinase (ILK) (for review, [106,107]). Overexpression of constitutively active Akt in skeletal muscles of dystrophin-deficient $m d x$ mice results in increased abundance of utrophin and $\alpha 7 \beta 1$ integrin, which leads to improvements in force generation
$[108,109]$. Interestingly, overexpression of threefold levels of SSPN results in amelioration of $m d x$ dystrophic pathology through stabilization of the UGC and $\alpha 7 \beta 1$ integrin at the sarcolemma, and activation of Akt and downstream p70S6K [19,70]. Conversely, the Akt/ p70S6K pathway and activation of the IGF receptor is depressed in SSPN-deficient mice, rendering the muscle unable to repair efficiently after cardiotoxin-induced injury (Figure 4) [19]. Pretreatment of SSPN-null muscle with adenovirus expressing constitutively active Akt increased the UGC to normal levels and restored muscle regeneration after cardiotoxin-injury (Figure 4) [19]. The conclusion from these experiments is that SSPN modulates utrophin protein levels at least in part through Akt/p70S6K signaling pathways (Figure 5).

\section{A chaperone-like function for sarcospan is emerging}

It has been assumed that the prematurely truncated dystrophin protein produced from the $m d x$ mutation is
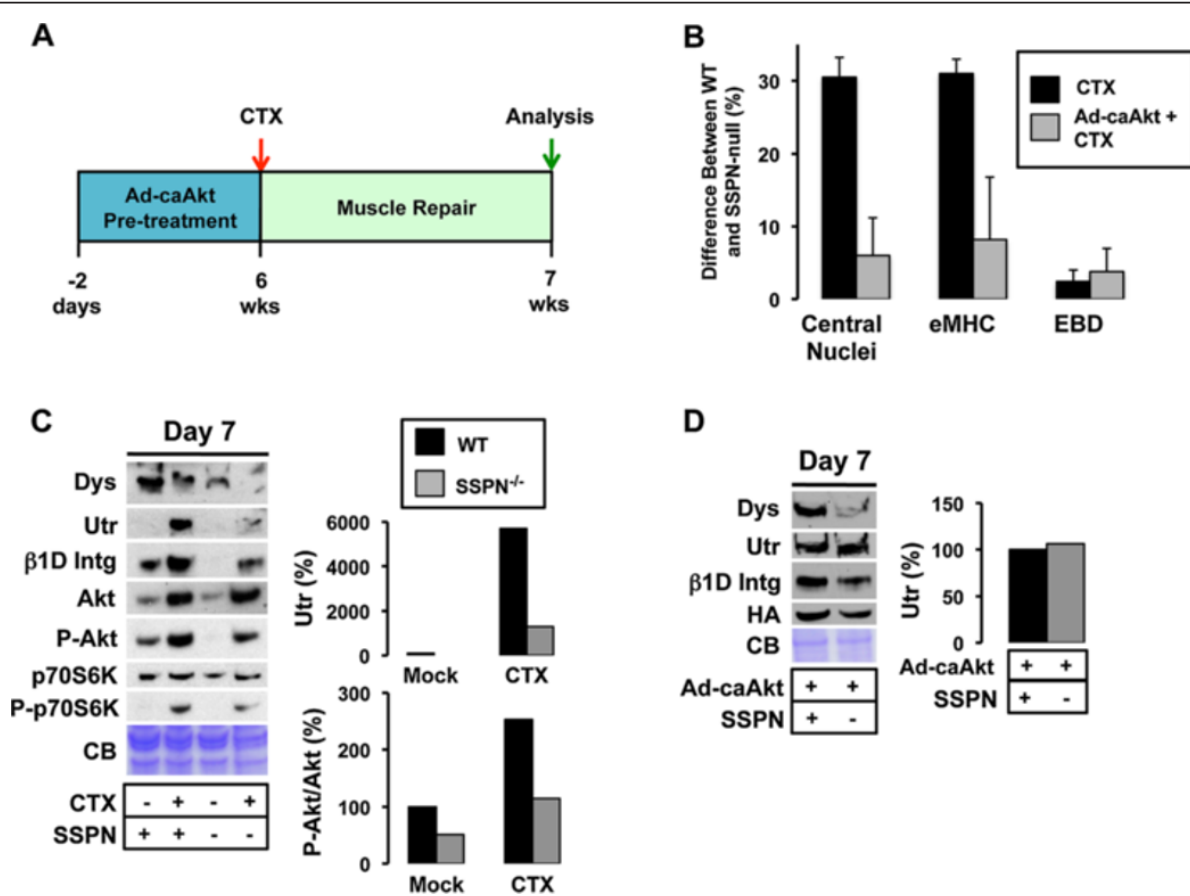

D

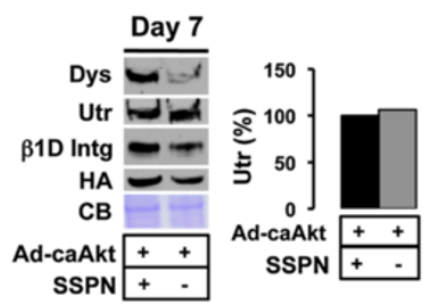

Figure 4 Muscle recovery from cardiotoxin injury requires SSPN-dependent Akt activation. (A) An acute injury model was used to investigate muscle repair in wild-type and SSPN-null mice. Quadriceps injected with equivalent volumes of saline (mock) and cardiotoxin dissolved in saline (CTX) were evaluated. CTX causes localized regions of myofiber necrosis followed by regeneration (for review, [125]). Mice at six weeks of age were injected with CTX (or mock) and analyzed after seven days. To test the dependency of muscle repair on Akt signaling, a subset of mice was pre-treated with adenovirus containing constitutively active Akt (Ad-caAkt) two days prior to CTX treatment. (B) Analysis was performed using H\&E, laminin/eMHC, and laminin/EBD stained sections from quadriceps muscle. SSPN-deficient mice exhibit increased active regeneration (eMHC, 30\%) seven days after CTX injury when wild-type mice have already undergone successful repair (black). Administration of Ad-caAkt prior to CTX treatment rescued the repair defect in SSPN-deficient mice (grey). (C) Immunoblot analysis of RIPA quadriceps lysates revealed reductions in the levels of dystrophin (Dys), utrophin (Utr), integrin (B1 integrin), phosphorylated Akt (P-Akt), and phosphorylated p70S6K (P-p70S6K) in SSPN-null mice compared to wild-type. Quantification of utrophin and P-Akt is provided. Coomassie blue (CB) serves as a loading control. (D) Immunoblot analysis of RIPA lysates from quadriceps pre-treated with Ad-caAkt revealed reductions in the levels of dystrophin (Dys) and integrin ( $\beta 1$ integrin) in SSPN-null mice compared to wild-type. Utrophin levels were restored in SSPN-null mice compared to wild-type mice with supplementation of active Akt (right). These data reveal that SSPN is upstream of the Akt signaling pathway regulating utrophin expression. The Ad-caAkt contains the HA-tag for detection [19]. RIPA, radioimmunoprecipitation assay. 


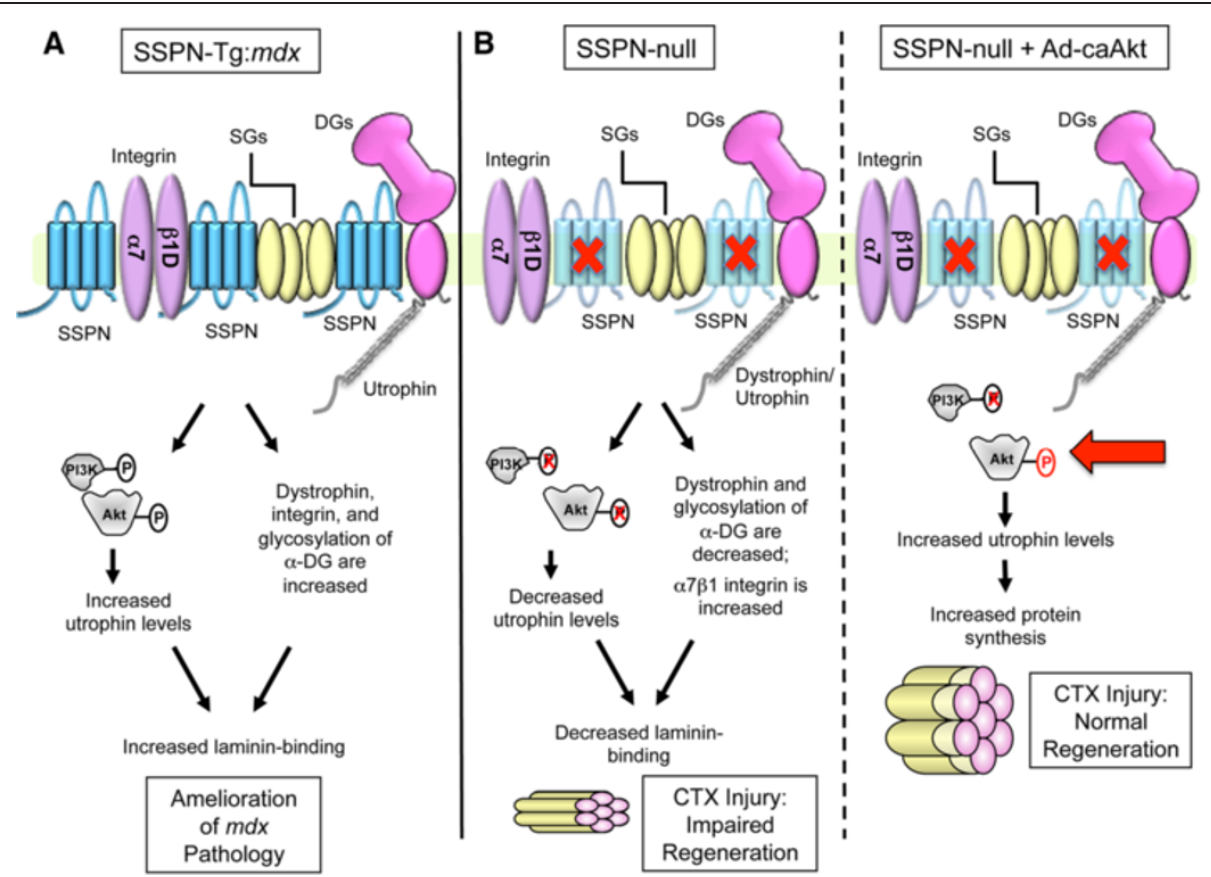

Figure 5 Sarcospan is a critical regulator of laminin-binding receptors in muscle. (A) The DGC/UGC and a7 $\beta 1$ integrin at the sarcolemma in $m d x^{3.0}$ (SSPN-Tg:mdx) muscle is depicted. The dystroglycans (DGs; pink), sarcoglycans (SGs; yellow), sarcospan (SSPN; blue), dystrophin (grey) and integrins (purple) are shown. Overexpression of SSPN in $m d x$ muscle elicits a series of molecular events that lead to restoration of laminin binding, amelioration of pathology, and restoration of membrane integrity [19]. As shown in the illustration, SSPN activates Akt, which stabilizes utrophin, and increases the abundance of integrin and WFA-reactive a-DG at the cell surface. SSPN facilitates increased CT antigen modification of a-DG and enhances transportation of utrophin-DG at the sarcolemma [19]. Collectively, these events lead to stabilization of the sarcolemmal membrane and amelioration of dystrophic pathology. (B) SSPN-null muscle exhibits decreased dystrophin and Akt activation followed by decreased expression of utrophin, resulting in the reduction of laminin-binding to a-DG (middle panel) [19]. Acute muscle injury by cardiotoxin injection into SSPN-null muscle impairs muscle regeneration (right) [19]. However, pre-treatment of SSPN-null mice with adenovirus containing constitutively active Akt (Ad-caAkt) restored the activation of downstream p70S6K, utrophin expression, and improved muscle regeneration (right panel). These studies reveal the importance of sarcospan and Akt in regulating utrophin expression that is critical for muscle repair. CT, cytotoxic T cell; DGC, dystrophin-glycoprotein complex; UGC, utrophin-glycoprotein complex; WFA, Wisteria floribunda agglutinin.

rapidly degraded in muscle based on lack of its detection in whole skeletal muscle extracts. However, recent work has revealed that truncated dystrophin protein is synthesized in $m d x$ mice [19]. In fact, truncated dystrophin proteins are produced and detected in high abundance in ER/golgi compartments in $m d x$ muscle, suggesting that they accumulate in intracellular compartments due to insufficient transportation to the cell surface [19]. These data are exciting as they reveal for the first time that truncated dystrophin fragments are synthesized in $m d x$ muscle, but then retained in intracellular membrane compartments rather than properly transported to the sarcolemma.

In addition to its role at the cell surface, a role for SSPN within the ER/golgi is suggested from recent studies. Biochemical analysis of ER/golgi membranes isolated from $m d x$ muscle revealed abundant levels of utrophin and $\alpha$-DG relative to wild-type [19]. Interestingly, utrophin and $\alpha$-DG are reduced in ER/golgi preparations from SSPN transgenic $m d x$ muscle while these same proteins are increased in abundance at the sarcolemma, suggesting that SSPN possesses chaperonelike functions to improve protein folding and/or trafficking to the cell surface (Figure 5).

\section{Sarcospan as a candidate disease gene}

The sarcospan gene is localized to human chromosome $12 \mathrm{p} 11.2$ and is encoded by three small exons that are separated by very large introns $[8,9]$. A novel exon 4 was recently identified to encode for an alternative Cterminal region in humans. In fact, alternate mRNA splicing of human SSPN exons 1 and 2 to exon 4 generates a protein called microspan $(\mu \mathrm{SPN})$ that lacks transmembrane domains 3 and 4 as well as the LEL so that the resultant protein has only two transmembrane spans and a novel intracellular C-terminus [10]. $\mu \mathrm{SPN}$ does not interact with the DGC and its expression is maintained in dystrophin-deficient muscle. Although $\mu \mathrm{SPN}$ is not localized to the sarcolemma, it is enriched in the sarcoplasmic reticulum (SR) [10]. Overexpression of $\mu \mathrm{SPN}$ in skeletal muscle of transgenic mice reduces levels of ryanodine receptor, dihydropyridine receptor as well as 
SERCA-1 resulting in aberrant triad morphology [10]. $\mu S P N$ is also reduced in isolated SR membranes of $\delta$-SG-null muscle contributing to SERCA dysfunction [110]. Given that both SSPN and $\mu$ SPN interact with proteins that are critical to skeletal muscle function, it can be hypothesized that genetic mutations affecting SSPN function would have significant consequences for muscle. PCR-based approaches to screen muscular dystrophy patients for possible abnormalities within the SSPN gene have not yet produced any disease-causing mutations, although several single-nucleotide polymorphisms were identified in exons 2 and 3 [111]. SSPN was also excluded as a candidate disease gene for congenital fibrosis of the extraocular muscle (CFEOM), which is an autosomal dominant disorder linked to the pericentromere of chromosome 12 [112,113]. These findings may come as no surprise given the apparently normal phenotype of SSPN-deficient mice [93]. However, re-analysis of SSPN-deficient mice revealed significant phenotypes in muscle of aged mice and after exposure to conditions of cellular stress that may have implications for disease (Figure 5) [14,19]. Furthermore, the idea that SSPN may serve as a chaperone to improve cell surface expression of the DGC and UGC make it an excellent candidate as a genetic modifier of disease.

\section{Conclusions}

Overexpression of many proteins and compounds ameliorates dystrophic pathology in the $m d x$ mouse by increasing UGC abundance at the extrasynaptic sarcolemma. A sampling of these includes: CT GalNAc transferase (Galgt2) [73], ADAM12 [114], heregulin [115], L-arginine [116,117], activated calcineurin-A alpha [118], N-acetylcysteine [119-121], activated Akt [108,109], GW501516 (activates PPAR beta/delta) [122], artificial gene Jazz [123], and biglycan [124]. Several studies have now revealed that SSPN can be added to this list of secondary proteins that modify utrophin expression $[19,69]$. The mechanism by which SSPN increases expression of utrophin involves activation of Akt signaling and increased glycosylation of $\alpha$-DG, likely by increased modification of Galgt2 [19]. Introduction of constitutively active Akt or Galgt2 alone also improves extrasynaptic utrophin expression, strongly suggesting that SSPN, Akt, and Galgt2 may act via a common or overlapping pathway(s). It will be important to determine whether every gene that increases utrophin expression also alters Akt and $\alpha$-DG glycosylation, which would provide further evidence for a common posttranscriptional mechanism controlling utrophin abundance. Furthermore, these data reveal that there are multiple targets that affect utrophin, which is encouraging for pharmacological and gene-based therapies. SSPN also increases expression of Itga7, and future studies will determine whether Itga7 and/or utrophin are required for SSPN's 'rescue' effect. It is also critical to investigate whether Itga7 levels are affected by the many other genes that increase utrophin expression, which would reveal important mechanisms regulating lamininbinding receptors in skeletal muscle. SSPN is a promising therapeutic target, particularly for adeno-associated virus delivery due to its small size and low potential for unwanted immune reaction. Future studies will reveal the potential of this small protein to alleviate the significant problem of DMD.

\section{Abbreviations}

BTX: bungarotoxin; $\mathrm{CCH}$ : chronic constant hypoxia; $\mathrm{ClH}$ : chronic intermittent hypoxia; CSA: cross-sectional area; CT: cytotoxic T cell; DAP: dystrophinassociated protein; DEAE: diethylaminoethyl; DG: dystroglycan; DGC: dystrophin-glycoprotein complex; DKO: double knockout; DMD: Duchenne muscular dystrophy; Dys: dystrophin; EBD: Evans blue dye; EDL: extensor digitorum longus; IGF-1: insulin-like growth factor; ILK: integrinlinked kinase; Intg: integrin; LEL: large extracellular loop; NMJ: neuromuscular junction; PCR: polymerase chain reaction; SDS: sodium dodecyl sulfate; SG: sarcoglycan; SSPN: sarcospan; UGC: utrophin-glycoprotein complex; Utr: utrophin; WFA: Wisteria floribunda agglutinin; sWGA: succinylated wheat germ agglutinin; $\mu S P N$ : microspan.

\section{Competing interests}

The authors declare that they have no competing interests.

\section{Authors' contributions}

Both authors contributed to writing and preparation of figures for the manuscript. All authors have read and approved the final manuscript.

\section{Authors' information}

Rachelle H. Crosbie-Watson, Ph.D. is a Professor of Integrative Biology and Physiology at the University of California Los Angeles and her research group is focused on investigation of macromolecular adhesion complexes at the cell surface in normal and dystrophic skeletal muscle. Professor CrosbieWatson earned a Ph.D. in biochemistry from the University of California Los Angeles investigating structure-function relationships of contractile proteins and she identified sarcospan during her MDA-sponsored postdoctoral fellowship at the University of lowa College of Medicine with Professor Kevin P. Campbell (HHMI).

Jamie L. Marshall, Ph.D. is a postdoctoral researcher in Dr. Crosbie-Watson's laboratory at the University of California Los Angeles. Dr. Marshall earned a Ph.D. in Molecular, Cellular, and Integrative Physiology from the University of California Los Angeles investigating the role of sarcospan in the adhesion glycoprotein complexes at the sarcolemma. Dr. Marshall pioneered purification the utrophin-glycoprotein complex [69] and discovered novel deficits of this complex in sarcospan-deficient muscle $[14,19$,$] . Dr. Marshall$ has received numerous predoctoral fellowships as well as a postdoctoral fellowship based on these studies. Dr. Marshall has extensive experience in genetics, analysis of dystrophic mouse models, and detailed biochemical investigation of the dystrophin- and utrophin-glycoprotein complexes.

\section{Acknowledgements}

This work was supported by grants from the Genetic Mechanisms Predoctoral Training Fellowship USPHS National Research Service Award GM07104, the Edith Hyde Fellowship, the Eureka Pre-doctoral Training Fellowship, and the Ruth L. Kirschstein National Research Service Award T32AR059033 from the National Institute of Arthritis and Musculoskeletal and Skin Diseases to J.L.M.; NIH/NIAMS (R01 AR048179) to R.C.W.

\section{Author details}

${ }^{1}$ Department of Integrative Biology and Physiology, University of California Los Angeles, 610 Charles E. Young Drive East, Terasaki Life Sciences Building, Los Angeles, CA 90095, USA. ${ }^{2}$ Center for Duchenne Muscular Dystrophy, University of California Los Angeles, Los Angeles, CA 90095, USA. ${ }^{3}$ Molecular Biology Institute, University of California Los Angeles, Los Angeles, CA 90095, USA. 
Received: 16 September 2012 Accepted: 27 November 2012

Published: 3 January 2013

\section{References}

1. Campbell KP, Kahl SD: Association of dystrophin and an integral membrane glycoprotein. Nature 1989, 338:259-262.

2. Ervasti JM, Ohlendieck K, Kahl SD, Gaver MG, Campbell KP: Deficiency of a glycoprotein component of the dystrophin complex in dystrophic muscle. Nature 1990, 345:315-319.

3. Yoshida M, Ozawa E: Glycoprotein complex anchoring dystrophin to sarcolemma. J Biochem 1990, 108:748-752.

4. Ervasti JM, Kahl SD, Campbell KP: Purification of dystrophin from skeletal muscle. J Biol Chem 1991, 266:9161-9165.

5. Ervasti JM, Campbell KP: Membrane organization of the dystrophinglycoprotein complex. Cell 1991, 66:1121-1131.

6. Sandona D, Betto R: Sarcoglycanopathies: molecular pathogenesis and therapeutic prospects. Expert Rev Mol Med 2009, 11:e28.

7. Crosbie RH, Heighway J, Venzke DP, Lee JC, Campbell KP: Sarcospan: the $25 \mathrm{kDa}$ transmembrane component of the dystrophin-glycoprotein complex. J Biol Chem 1997, 272:31221-31224.

8. Heighway J, Betticher DC, Hoban PR, Altermatt HJ, Cowen R: Coamplification in tumors of KRAS2, type 2 inositol 1,4,5 triphosphate receptor gene, and a novel human gene. KRAG Genomics 1996, 35:207-214

9. Scott AF, Elizaga A, Morrell J, Bergen A, Penno MB: Characterization of a gene coamplified with Ki-ras in Y1 murine adrenal carcinoma cells that codes for a putative membrane protein. Genomics 1994, 20:227-230.

10. Miller G, Peter AK, Espinoza E, Heighway J, Crosbie RH: Over-expression of microspan, a novel component of the sarcoplasmic reticulum, causes severe pathology with triad abnormalities. J Muscle Res Cell Motility 2006, 27:545-558.

11. Groh S, Zong H, Goddeeris MM, Lebakken CS, Venzke D, Pessin JE, Campbell KP: Sarcoglycan complex: implications for metabolic defects in muscular dystrophies. J Biol Chem 2009, 284:19178-19182

12. Muñoz $P$, Rosemblatt $M$, Testar $X$, Palacin $M$, Zorzano A: Isolation and characterization of distinct domains of sarcolemma and T-tubules from rat skeletal muscle. Biochem J 1995, 307:273-280.

13. Crosbie RH, Yamada H, Venzke DP, Lisanti MP, Campbell KP: Caveolin-3 is not an integral component of the dystrophin-glycoprotein complex. FEBS Lett 1998, 427:279-282.

14. Marshall JL, Chou E, Oh J, Kwok A, Burkin DJ, Crosbie-Watson RH: Dystrophin and utrophin expression require sarcospan: loss of alpha7 integrin exacerbates a newly discovered muscle phenotype in sarcospan-null mice. Hum Mol Genet 2012, 21:4378-4393.

15. Ibraghimov-Beskrovnaya O, Ervasti JM, Leveille CJ, Slaughter CA, Sernett SW, Campbell KP: Primary structure of dystrophin-associated glycoproteins linking dystrophin to the extracellular matrix. Nature 1992, 355:696-702.

16. Ervasti JM, Campbell KP: A role for the dystrophin-glycoprotein complex as a transmembrane linker between laminin and actin. J Cell Biol 1993, 122:809-823.

17. Yamada H, Shimizu T, Tanaka T, Campbell KP, Matsumura K: Dystroglycan is a binding protein of laminin and merosin in peripheral nerve. FEBS Lett 1994, 352:49-53.

18. Yamada H, Chiba A, Endo T, Kobata A, Anderson LV, Hori H, Fukuta-Ohi H, Kanazawa I, Campbell KP, Shimizu T, Matsumura K: Characterization of dystroglycan-laminin interaction in peripheral nerve. J Neurochem 1996, 66:1518-1524.

19. Marshall JL, Holmberg J, Chou E, Ocampo AC, Oh J, Lee J, Peter AK, Martin PT, Crosbie-Watson RH: Sarcospan-dependent Akt activation is required for utrophin expression and muscle regeneration. J Cell Biol 2012, 197:1009-1027.

20. Berditchevski F: Complexes of tetraspanins with integrins: more than meets the eye. J Cell Sci 2001, 114:4143-4151.

21. Boucheix C, Rubinstein E: Tetraspanins. Cell Mol Life Sci 2001, 58:1189-1205.

22. Yunta M, Lazo PA: Tetraspanin proteins as organisers of membrane microdomains and signalling complexes. Cell Signal 2003, 15:559-564.

23. Charrin S, le Naour F, Silvie O, Milhiet PE, Boucheix C, Rubinstein E: Lateral organization of membrane proteins: tetraspanins spin their web. Biochem J 2009, 420:133-154.

24. Miller G, Wang EL, Nassar KL, Peter AK, Crosbie RH: Structural and functional analysis of the sarcoglycan-sarcospan subcomplex. Exp Cell Res 2007, 313:639-651.
25. Hupp K, Siwarski D, Mock BA, Kinet JP: Gene mapping of the three subunits of the high affinity FCR for lgE to mouse chromosomes 1 and 19. J Immunol 1989, 143:3787-3791.

26. Einfeld DA, Brown JP, Valentine MA, Clark EA, Ledbetter JA: Molecular cloning of the human $B$ cell $C D 20$ receptor predicts a hydrophobic protein with multiple transmembrane domains. EMBO J 1988, 7:711-717

27. Tedder TF, Streuli M, Schlossman SF, Saito H: Isolation and structure of a CDNA encoding the B1 (CD20) cell-surface antigen of human B lymphocytes. Proc Natl Acad Sci U S A 1988, 85:208-212.

28. Stamenkovic I, Seed B: Analysis of two CDNA clones encoding the $B$ lymphocyte antigen CD20 (B1, Bp35), a type III integral membrane protein. J Exp Med 1988, 167:1975-1980.

29. Polyak MJ, Tailor SH, Deans JP: Identification of a cytoplasmic region of CD20 required for its redistribution to a detergent-insoluble membrane compartment. J Immunol 1998, 161:3242-3248.

30. Bubien JK, Zhou LJ, Bell PD, Frizzell RA, Tedder TF: Transfection of the CD20 cell surface molecule into ectopic cell types generates a Ca2+ conductance found constitutively in B lymphocytes. J Cell Biol 1993, 121:1121-1132.

31. Deans JP, Li H, Polyak MJ: CD20-mediated apoptosis: signalling through lipid rafts. Immunology 2002, 107:176-182.

32. Crosbie RH, Lebakken CS, Holt KH, Venzke DP, Straub V, Lee JC, Grady RM, Chamberlain JS, Sanes JR, Campbell KP: Membrane targeting and stabilization of sarcospan is mediated by the sarcoglycan subcomplex. J Cell Biol 1999, 145:153-165.

33. Jung D, Duclos F, Apostol B, Straub V, Lee JC, Allamand V, Venzke DP, Sunada Y, Moomaw CR, Leveille CJ, Slaughter CA, Crawford TO, McPherson JD, Campbell KP: Characterization of d-sarcoglycan, a novel component of the oligomeric sarcoglycan complex involved in limb-girdle muscular dystrophy. J Biol Chem 1996, 50:32321-32329.

34. Yoshida M, Suzuki A, Yamamoto H, Noguchi S, Mizuno Y, Ozawa E: Dissociation of the complex of dystrophin and its associated proteins into several unique groups by n-octyl beta-D-glucoside. Eur J Biochem 1994, 222:1055-1061

35. Durbeej $M$, Campbell KP: Biochemical characterization of the epithelial dystroglycan complex. J Biol Chem 1999, 274:26609-26616.

36. Durbeej M, Cohn RD, Hrstka RF, Moore SA, Allamand V, Davidson BL, Williamson RA, Campbell KP: Disruption of the beta-sarcoglycan gene reveals pathogenetic complexity of limb-girdle muscular dystrophy type 2E. Mol Cell 2000, 5:141-151.

37. Cohn RD, Durbeej M, Moore SA, Coral-Vazquez R, Prouty S, Campbell KP: Prevention of cardiomyopathy in mouse models lacking the smooth muscle sarcoglycan-sarcospan complex. J Clin Invest 2001, 107:R1-R7.

38. Durbeej M, Sawatzki SM, Barresi R, Schmainda KM, Allamand V, Michele DE, Campbell KP: Gene transfer establishes primacy of striated vs. smooth muscle sarcoglycan complex in limb-girdle muscular dystrophy. Proc Natl Acad Sci U S A 2003, 100:8910-8915.

39. Heydemann A, McNally EM: Consequences of disrupting the dystrophinsarcoglycan complex in cardiac and skeletal myopathy. Trends Cardiovasc Med 2007, 17:55-59.

40. Carmignac V, Durbeej M: Cell-matrix interactions in muscle disease. J Pathol 2012, 226:200-218.

41. Roberds SL, Ervasti JM, Anderson RD, Ohlendieck K, Kahl SD, Zoloto D, Campbell KP: Disruption of the dystrophin-glycoprotein complex in the cardiomyopathic hamster. J Biol Chem 1993, 268:11496-11499.

42. Iwata Y, Nakamura H, Mizuno Y, Yoshida M, Ozawa E, Shigekawa M: Defective association of dystrophin with sarcolemmal glycoproteins in the cardiomyopathic hamster heart. FEBS Lett 1993, 329:227-231.

43. Duclos F, Straub V, Moore SA, Venzke DP, Hrstka RF, Crosbie RH, Durbeej M, Lebakken CS, Ettinger AJ, van der Meulen J, Holt KH, Lim LE, Sanes JR, Davidson BL, Faulkner JA, Williamson R, Campbell KP: Progressive muscular dystrophy in alpha-sarcoglycan-deficient mice. J Cell Biol 1998, 142:1461-1471.

44. Coral-Vazquez R, Cohn RD, Moore SA, Hill JA, Weiss RM, Davisson RL, Straub V, Barresi R, Bansal D, Hrstka RF, Williamson R, Campbell KP: Disruption of the sarcoglycan-sarcospan complex in vascular smooth muscle: a novel mechanism for cardiomyopathy and muscular dystrophy. Cell 1999 . 98:465-474.

45. Araishi K, Sasaoka T, Imamura M, Noguchi S, Hama H, Wakabayashi E, Yoshida M, Hori T, Ozawa E: Loss of the sarcoglycan complex and sarcospan leads to muscular dystrophy in beta-sarcoglycan -deficient mice. Hum Mol Genet 1999, 8:1589-1598. 
46. Crawford GE, Faulkner JA, Crosbie RH, Campbell KP, Froehner SC, Chamberlain JS: Assembly of the dystrophin-associated protein complex does not require the dystrophin $\mathrm{COOH}$-terminal domain. J Cell Biol 2000 150:1399-1410.

47. Hack AA, Ly CT, Jiang F, Clendenin CJ, Sigrist KS, Wollmann RL, McNally EM: Gamma-sarcoglycan deficiency leads to muscle membrane defects and apoptosis independent of dystrophin. J Cell Biol 1998, 142:1279-1287.

48. Hayashi K, Wakayama Y, Inoue M, Kojima H, Shibuya S, Jimi T, Hara H, Oniki $\mathrm{H}$ : Sarcospan: ultrastructural localization and its relation to the sarcoglycan complex. Micron 2006, 37:591-596.

49. Straub V, Ettinger AJ, Durbeej M, Venzke DP, Cutshall S, Sanes JR, Campbell KP: Epsilon-sarcoglycan replaces alpha-sarcoglycan in smooth muscle to form a unique dystrophin-glycoprotein complex. J Biol Chem 1999, 274:27989-27996.

50. Barresi R, Moore SA, Stolle CA, Mendell JR, Campbell KP: Expression of gamma -sarcoglycan in smooth muscle and its interaction with the smooth muscle sarcoglycan-sarcospan complex. J Biol Chem 2000, 275:38554-38560.

51. Ramirez-Sanchez I, Rosas-Vargas H, Ceballos-Reyes G, Salamanca F, CoralVazquez RM: Expression analysis of the SG-SSPN complex in smooth muscle and endothelial cells of human umbilical cord vessels. J Vasc Res 2005, 42:1-7.

52. Grisoni K, Martin E, Gieseler K, Mariol MC, Segalat L: Genetic evidence for a dystrophin-glycoprotein complex (DGC) in Caenorhabditis elegans. Gene 2002, 294:77-86.

53. Greener MJ, Roberts RG: Conservation of components of the dystrophin complex in Drosophila. FEBS Lett 2000, 482:13-18.

54. Love DR, Hill DF, Dickson G, Spurr NK, Byth BC, Marsden RF, Walsh FS, Edwards $\mathrm{YH}$, Davies KE: An autosomal transcript in skeletal muscle with homology to dystrophin. Nature 1989, 339:55-58.

55. Khurana TS, Watkins SC, Chafey P, Chelly J, Tome FM, Fardeau M, Kaplan JC, Kunkel LM: Immunolocalization and developmental expression of dystrophin related protein in skeletal muscle. Neuromuscl Disord 1991, 1:185-194.

56. Matsumura K, Ervasti JM, Ohlendieck K, Kahl SD, Campbell KP: Association of dystrophin-related protein with dystrophin-associated proteins in mdx mouse muscle. Nature 1992, 360:588-591.

57. Zhao J, Yoshioka K, Miyatake M, Miike T: Dystrophin and a dystrophinrelated protein in intrafusal muscle fibers, and neuromuscular and myotendinous junctions. Acta Neuropathol 1992, 84:141-146.

58. Nguyen TM, Ellis JM, Love DR, Davies KE, Gatter KC, Dickson G, Morris GE: Localization of the DMDL gene-encoded dystrophin-related protein using a panel of nineteen monoclonal antibodies: presence at neuromuscular junctions, in the sarcolemma of dystrophic skeletal muscle, in vascular and other smooth muscles, and in proliferating brain cell lines. J Cell Biol 1991, 115:1695-1700.

59. Tinsley JM, Potter AC, Phelps SR, Fisher R, Trickett Jl, Davies KE: Amelioration of the dystrophic phenotype of $\mathrm{mdx}$ mice using a truncated utrophin transgene. Nature 1996, 384:349-353.

60. Rafael JA, Tinsley JM, Potter AC, Deconinck AE, Davies KE: Skeletal musclespecific expression of a utrophin transgene rescues utrophin-dystrophin deficient mice. Nat Genet 1998, 19:79-82.

61. Tinsley J, Deconinck N, Risher R, Kahn D, Phelps S, Gillis JM, Davies K: Expression of full-length utrophin prevents muscular dystrophy in $\mathrm{mdx}$ mice. Nat Med 1998, 4:1441-1444.

62. Deconinck N, Tinsley J, De Backer F, Fisher R, Kahn D, Phelps S, Davies K, Gillis JM: Expression of truncated utrophin leads to major functional improvements in dystrophin-deficient muscles of mice. Nat Med 1997, 3:1216-1221.

63. Gilbert R, Nalbantoglu J, Petrof BJ, Ebihara S, Guibinga GH, Tinsley JM, Kamen A, Massie B, Davies KE, Karpati G: Adenovirus-mediated utrophin gene transfer mitigates the dystrophic phenotype of mdx mouse muscles. Hum Gene Ther 1999, 10:1299-1310.

64. Fisher R, Tinsley JM, Phelps SR, Squire SE, Townsend ER, Martin JE, Davies KE: Non-toxic ubiquitous over-expression of utrophin in the $\mathrm{mdx}$ mouse. Neuromuscul Disord 2001, 11:713-721

65. Deol JR, Danialou G, Larochelle N, Bourget M, Moon JS, Liu AB, Gilbert R, Petrof BJ, Nalbantoglu J, Karpati G: Successful compensation for dystrophin deficiency by a helper-dependent adenovirus expressing fulllength utrophin. Mol Ther 2007, 15:1767-1774

66. Odom GL, Gregorevic P, Allen JM, Finn E, Chamberlain JS: Microutrophin delivery through rAAV6 increases lifespan and improves muscle function in dystrophic dystrophin/utrophin-deficient mice. Mol Ther 2008, 16:1539-1545.
67. Sonnemann KJ, Heun-Johnson H, Turner AJ, Baltgalvis KA, Lowe DA, Ervasti JM: Functional substitution by TAT-utrophin in dystrophin-deficient mice. PLoS Med 2009, 6:e1000083.

68. Squire S, Raymackers JM, Vandebrouck C, Potter A, Tinsley J, Fisher R, Gillis JM, Davies KE: Prevention of pathology in $\mathrm{mdx}$ mice by expression of utrophin: analysis using an inducible transgenic expression system. Hum Mol Genet 2002, 11:3333-3344.

69. Peter AK, Marshall JL, Crosbie RH: Sarcospan reduces dystrophic pathology: stabilization of the utrophin-glycoprotein complex. J Cell Biol 2008, 183:419-427.

70. Peter AK, Miller G, Crosbie RH: Disrupted mechanical stability of the dystrophin-glycoprotein complex causes severe muscular dystrophy in sarcospan transgenic mice. J Cell Sci 2007, 120:996-1008.

71. Smith PL, Lowe JB: Molecular cloning of a murine $\mathrm{N}$-acetylgalactosamine transferase CDNA that determines expression of the T lymphocyte-specific CT oligosaccharide differentiation antigen. J Biol Chem 1994, 269:15162-15171.

72. Xia B, Hoyte K, Kammesheidt A, Deerinck T, Ellisman M, Martin PT: Overexpression of the CT GalNAc transferase in skeletal muscle alters myofiber growth, neuromuscular structure, and laminin expression. Dev Biol 2002, 242:58-73.

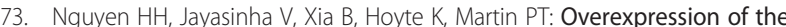
cytotoxic T cell GalNAc transferase in skeletal muscle inhibits muscular dystrophy in mdx mice. Proc Natl Acad Sci U S A 2002, 99:5616-5621.

74. Xu R, Camboni M, Martin PT: Postnatal overexpression of the CT GalNAC transferase inhibits muscular dystrophy in $\mathrm{mdx}$ mice without altering muscle growth or neuromuscular development: evidence for a utrophinindependent mechanism. Neuromuscul Disord 2007, 17:209-220.

75. Martin PT, Sanes JR: Role for a synapse-specific carbohydrate in agrininduced clustering of acetylcholine receptors. Neuron 1995, 14:743-754.

76. Hoyte K, Kang C, Martin PT: Definition of pre- and postsynaptic forms of the $C T$ carbohydrate antigen at the neuromuscular junction: ubiquitous expression of the $C T$ antigens and the $C T$ GalNAc transferase in mouse tissues. Brain Res Mol Brain Res 2002, 109:146-160.

77. Martin PT: Glycobiology of the neuromuscular junction. J Neurocytol 2003, 32:915-929.

78. Durko M, Allen C, Nalbantoglu J, Karpati G: CT-GalNAc transferase overexpression in adult mice is associated with extrasynaptic utrophin in skeletal muscle fibres. J Muscle Res Cell Motil 2010, 31:181-193.

79. Hijikata T, Murakami T, Ishikawa H, Yorifuji H: Plectin tethers desmin intermediate filaments onto subsarcolemmal dense plaques containing dystrophin and vinculin. Histochem Cell Biol 2003, 119:109-123.

80. Garcia-Alvarez B, de Pereda JM, Calderwood DA, Ulmer TS, Critchley D, Campbell ID, Ginsberg MH, Liddington RC: Structural determinants of integrin recognition by talin. Mol Cell 2003, 11:49-58.

81. Litjens SH, Wilhelmsen $\mathrm{K}$, de Pereda JM, Perrakis A, Sonnenberg A: Modeling and experimental validation of the binary complex of the plectin actin-binding domain and the first pair of fibronectin type III (FNIII) domains of the beta4 integrin. J Biol Chem 2005, 280:22270-22277.

82. Rezniczek GA, Konieczny P, Nikolic B, Reipert S, Schneller D, Abrahamsberg C, Davies KE, Winder SJ, Wiche G: Plectin If scaffolding at the sarcolemma of dystrophic (mdx) muscle fibers through multiple interactions with beta-dystroglycan. J Cell Biol 2007, 176:965-977.

83. Grewal PK, Holzfeind PJ, Bittner RE, Hewitt JE: Mutant glycosyltransferase and altered glycosylation of alpha-dystroglycan in the myodystrophy mouse. Nat Genet 2001, 28:151-154.

84. Michele DE, Barresi R, Kanagawa M, Saito F, Cohn RD, Satz JS, Dollar J, Nishino I, Kelley RI, Somer H, Straub V, Mathews KD, Moore SA, Campbell KP: Post-translational disruption of dystroglycan ligand interactions in congenital muscular dystrophies. Nature 2002, 418:417-421.

85. Holzfeind PJ, Grewal PK, Reitsamer HA, Kechvar J, Lassmann H, Hoeger $\mathrm{H}_{\text {, }}$ Hewitt JE, Bittner RE: Skeletal, cardiac and tongue muscle pathology, defective retinal transmission, and neuronal migration defects in the Large(myd) mouse defines a natural model for glycosylation-deficient muscle - eye - brain disorders. Hum Mol Genet 2002, 11:2673-2687.

86. Kanagawa M, Saito F, Kunz S, Yoshida-Moriguchi T, Barresi R, Kobayashi YM Muschler J, Dumanski JP, Michele DE, Oldstone MB, Campbell KP: Molecular recognition by LARGE is essential for expression of functional dystroglycan. Cell 2004, 117:953-964.

87. Yoshida-Moriguchi T, Yu L, Stalnaker SH, Davis S, Kunz S, Madson M, Oldstone MB, Schachter H, Wells L, Campbell KP: O-mannosyl 
phosphorylation of alpha-dystroglycan is required for laminin binding. Science 2010, 327:88-92.

88. Turk R, Sterrenburg E, van der Wees CG, de Meijer EJ, de Menezes RX, Groh S, Campbell KP, Noguchi S, van Ommen GJ, Dunnen JT, t Hoen PA: Common pathological mechanisms in mouse models for muscular dystrophies. FASEB J 2006, 20:127-129.

89. Uaesoontrachoon K, Wasgewatte Wijesinghe DK, Mackie EJ, Pagel CN: Osteopontin deficiency delays inflammatory infiltration and the onset of muscle regeneration in a model of muscle injury. Dis Model Mech, in press.

90. Bargagli E, Olivieri C, Cintorino M, Refini RM, Bianchi N, Prasse A, Rottoli P: Calgranulin B (S100A9/MRP14): a key molecule in idiopathic pulmonary fibrosis? Inflammation 2011, 34:85-91.

91. Paliwal P, Pishesha N, Wijaya D, Conboy IM: Age dependent increase in the levels of osteopontin inhibits skeletal muscle regeneration. Aging (Albany NY) 2012, 4:553-566.

92. Zhou D, Wang J, Zapala MA, Xue J, Schork NJ, Haddad GG: Gene expression in mouse brain following chronic hypoxia: role of sarcospan in glial cell death. Physiol Genomics 2008, 32:370-379.

93. Lebakken CS, Venzke DP, Hrstka RF, Consolino CM, Faulkner JA, Williamson RA, Campbell KP: Sarcospan-deficient mice maintain normal muscle function. Mol Cell Biol 2000, 20:1669-1677.

94. Rubinstein E: The complexity of tetraspanins. Biochem Soc Trans 2011, 39:501-505.

95. Yanez-Mo M, Barreiro O, Gordon-Alonso M, Sala-Valdes M, Sanchez-Madrid F: Tetraspanin-enriched microdomains: a functional unit in cell plasma membranes. Trends Cell Biol 2009, 19:434-446.

96. Burkin DJ, Kim JE, Gu M, Kaufman SJ: Laminin and alpha7beta1 integrin regulate agrin-induced clustering of acetylcholine receptors. J Cell Sci 2000, 113:2877-2886.

97. Burkin DJ, Gu M, Hodges BL, Campanelli JT, Kaufman SJ: A functional role for specific spliced variants of the alpha7beta1 integrin in acetylcholine receptor clustering. J Cell Biol 1998, 143:1067-1075.

98. Mayer U, Saher G, Fassler R, Bornemann A, Echtermeyer F, von der Mark H, Miosge N, Poschl E, von der Mark K: Absence of integrin alpha 7 causes a novel form of muscular dystrophy. Nat Genet 1997, 17:318-323.

99. Nawrotzki R, Willem M, Miosge N, Brinkmeier H, Mayer U: Defective integrin switch and matrix composition at alpha 7-deficient myotendinous junctions precede the onset of muscular dystrophy in mice. Hum Mol Genet 2003, 12:483-495.

100. Grady RM, Teng H, Nichol MC, Cuttingham JC, Wilkinson RS, Sanes JR: Skeletal and cardiac myopathies in mice lacking utrophin and dystrophin: a model for Duchenne muscular dystrophy. Cell 1997, 90:729-738.

101. Deconinck AE, Rafael JA, Skinner JA, Brown SC, Potter AC, Metzinger L, Watt DJ, Dickson JG, Tinsley JM, Davies KE: Utrophin-dystrophin deficient mice as a model for Duchenne muscular dystrophy. Cell 1997, 90:717-727.

102. Rooney JE, Welser JV, Dechert MA, Flintoff-Dye NL, Kaufman SJ, Burkin DJ: Severe muscular dystrophy in mice that lack dystrophin and alpha7 integrin. J Cell Sci 2006, 119:2185-2195.

103. Burkin DJ, Wallace GQ, Nicol KJ, Kaufman DJ, Kaufman SJ: Enhanced expression of the alpha 7 beta 1 integrin reduces muscular dystrophy and restores viability in dystrophic mice. J Cell Biol 2001, 152:1207-1218.

104. Burkin DJ, Wallace GQ, Milner DJ, Chaney EJ, Mulligan JA, Kaufman SJ: Transgenic expression of \{alpha\}7\{beta\}1 integrin maintains muscle integrity, increases regenerative capacity, promotes hypertrophy, and reduces cardiomyopathy in dystrophic mice. Am J Pathol 2005, 166:253-263.

105. Liu J, Milner DJ, Boppart MD, Ross RS, Kaufman SJ: beta1D chain increases alpha7beta1 integrin and laminin and protects against sarcolemmal damage in mdx mice. Hum Mol Genet, 21:1592-1603.

106. Otto A, Patel K: Signalling and the control of skeletal muscle size. Exp Cell Res 2010, 316:3059-3066.

107. Glass D, Roubenoff R: Recent advances in the biology and therapy of muscle wasting. Ann N Y Acad Sci 2011, 1211:25-36.

108. Peter AK, Ko CY, Kim MH, Hsu N, Ouchi N, Rhie S, Izumiya Y, Zeng L, Walsh $\mathrm{K}$, Crosbie RH: Myogenic Akt signaling upregulates the utrophinglycoprotein complex and promotes sarcolemma stability in muscular dystrophy. Hum Mol Genet 2009, 18:318-327.

109. Kim MH, Kay DI, Rudra RT, Chen BM, Hsu N, Izumiya Y, Martinez L, Spencer MJ, Walsh K, Grinnell AD, Crosbie RH: Myogenic Akt signaling attenuates muscular degeneration, promotes myofiber regeneration and improves muscle function in dystrophin-deficient mdx mice. Hum Mol Genet 2011, 20:1324-1338

110. Solares-Perez A, Alvarez R, Crosbie RH, Vega-Moreno J, Medina-Monares J, Estrada FJ, Ortega A, Coral-Vazquez R: Altered calcium pump and secondary deficiency of gamma-sarcoglycan and microspan in sarcoplasmic reticulum membranes isolated from delta-sarcoglycan knockout mice. Cell Calcium 2010, 48:28-36.

111. Crosbie RH, Lim LE, Moore SA, Hirano M, Hays AP, Maybaum SW, Collin H, Dovico SA, Stolle CA, Fardeau M, Tomé FM, Campbell KP: Molecular and genetic characterization of sarcospan: insights into sarcoglycansarcospan interactions. Hum Mol Genet 2000, 9:2019-2027.

112. Engle EC, Kunkel LM, Specht LA, Beggs AH: Mapping a gene for congenital fibrosis of the extraocular muscles to the centromeric region of chromosome 12. Nat Genet 1994, 7:69-73.

113. O'Brien KF, Engle EC, Kunkel LM: Analysis of human sarcospan as a candidate gene for CFEOM1. BMC Genet 2001, 2:3.

114. Moghadaszadeh B, Albrechtsen R, Guo LT, Zaik M, Kawaguchi N, Borup RH, Kronqvist P, Schroder HD, Davies KE, Voit T, Nielsen FC, Engvall E, Wewer UM: Compensation for dystrophin-deficiency: ADAM12 overexpression in skeletal muscle results in increased alpha 7 integrin, utrophin and associated glycoproteins. Hum Mol Genet 2003, 12:2467-2479.

115. Krag TO, Bogdanovich S, Jensen CJ, Fischer MD, Hansen-Schwartz J, Javazon EH, Flake AW, Edvinsson L, Khurana TS: Heregulin ameliorates the dystrophic phenotype in mdx mice. Proc Natl Acad Sci U S A 2004 101:13856-13860.

116. Voisin V, Sebrie C, Matecki S, Yu H, Gillet B, Ramonatxo M, Israel M, De la Porte S: L-arginine improves dystrophic phenotype in $\mathrm{mdx}$ mice. Neurobiol Dis 2005, 20:123-130.

117. Barton ER, Morris L, Kawana M, Bish LT, Toursel T: Systemic administration of $\mathrm{L}$-arginine benefits $\mathrm{mdx}$ skeletal muscle function. Muscle Nerve 2005, 32:751-760

118. Stupka N, Plant DR, Schertzer JD, Emerson TM, Bassel-Duby R, Olson EN, Lynch GS: Activated calcineurin ameliorates contraction-induced injury to skeletal muscles of mdx dystrophic mice. J Physiol 2006, 575:645-656.

119. Whitehead NP, Pham C, Gervasio OL, Allen DG: N-Acetylcysteine ameliorates skeletal muscle pathophysiology in mdx mice. J Physiol 2008, 586:2003-2014.

120. Terrill JR, Radley-Crabb HG, Grounds MD, Arthur PG: N-Acetylcysteine treatment of dystrophic $\mathrm{mdx}$ mice results in protein thiol modifications and inhibition of exercise induced myofibre necrosis. Neuromuscul Disord 2012, 22:427-434.

121. de Senzi Moraes Pinto R, Ferretti R, Moraes LH, Neto HS, Marques MJ, Minatel E: N-Acetylcysteine treatment reduces TNF-alpha levels and myonecrosis in diaphragm muscle of $\mathrm{mdx}$ mice. Clin Nutr, in press.

122. Miura P, Chakkalakal JV, Boudreault L, Belanger G, Hebert RL, Renaud JM, Jasmin BJ: Pharmacological activation of PPARbeta/delta stimulates utrophin A expression in skeletal muscle fibers and restores sarcolemmal integrity in mature mdx mice. Hum Mol Genet 2009, 18:4640-4649.

123. Di Certo MG, Corbi N, Strimpakos G, Onori A, Luvisetto S, Severini C Guglielmotti A, Batassa EM, Pisani C, Floridi A, Benassi B, Fanciulli M, Magrelli A, Mattei E, Passananti C: The artificial gene Jazz, a transcriptional regulator of utrophin, corrects the dystrophic pathology in $\mathrm{mdx}$ mice. Hum Mol Genet, 19:752-760.

124. Amenta AR, Yilmaz A, Bogdanovich S, McKechnie BA, Abedi M, Khurana TS, Fallon JR: Biglycan recruits utrophin to the sarcolemma and counters dystrophic pathology in mdx mice. Proc Natl Acad Sci U S A 2011, 108:762-767.

125. Mann CJ, Perdiquero E, Kharraz Y, Aguilar S, Pessina P, Serrano AL, MunozCanoves P: Aberrant repair and fibrosis development in skeletal muscle. Skelet Muscle 2011, 1:21.

\section{doi:10.1186/2044-5040-3-1}

Cite this article as: Marshall and Crosbie-Watson: Sarcospan: a small protein with large potential for Duchenne muscular dystrophy. Skeletal Muscle 2013 3:1. 